lecturer at the University of St. Andrews he joined the staff of King's College, London, in 1950, and, since then, has occupied posts as lecturer, senior lecturer (1956), and reader in engineering science (1961). Dr. Zarek's researches fall mainly into two fields. First, he was one of the first workers in Britain in the field of biomechanics, the application of the principles of engineering to problems in surgery and medicine. His work in this area of research has done much to establish and advance the science. Secondly, he has sustained an interest in the metering of pulsating flow and has served as the chairman of the International Standards Organization Working Group for Pulsating Flow Measurement.

\section{Voluntary Service Overseas}

IN a written answer in the House of Commons on June 28, Mr. A. E. Oram, the Parliamentary Secretary to the Ministry of Overseas Development, stated that after consultations with the voluntary bodies and discussion in the Lockwood Committee, it had been agreed that the target for the graduate and qualified volunteer programme for 1966-67 should be 1,500. Voluntary Service Overseas intended to send out about 500 cadet volunteers (schoolleavers and young volunteers from industry), and the Government would meet 75 per cent of the British costs of 400 of these cadets and of the 1,300 graduates. The programme of the graduate volunteers was only 100 moro than this year's programme, which was proving difficult to complete. The voluntary bodies and the Government were agreed that quality should not be sacrificed for quantitv and that in 1966 Britain should concentrate on str $\ominus n$ nthening the selection of projects. For this purpose the voluntary societies intended to arrange more frequent visits to the developing countries by members of their staff to discuss, at first hand, the selection of projects and to evaluate the work their volunteers were doing. Extra staff would be recruited. where necessary and there would be fresh publicity to stimulate recruitmont, including a film about volunteers produced by the Central Office of Information.

\section{European Organization for Nuclear Research}

In reply to a question in the House of Commons on July 1, the Socretary of State for Education and Science, Mr. A. Crosland, stated that the Govornment had agreed in principle to participate in the project for adding intersecting storage rings to the $28 \cdot \mathrm{GeV}$ proton synchroton of the Europcan Organization for Nuclear Research at a cost of about $£ 28$ million, of which the United Kingdom's share would be rather less than $£ 7$ million over about $5 \cdot 5$ years. The formal decision might be taken by the participating States at a meeting of the Council in December. The intersecting storage rings would provide European high-energy physicists with a unique facility for maintaining a progranme of advanced research.

\section{The United Steel Companies}

STeEL is very much in the news at the present time and it is therefore not without portinent interest to read the Review of Progress 1964 recently published by the United Steel Companies, Ltd. (Pp. 52. Shefficld: The United Steel Companies, Ltd., 1965.) This report covers the period October 1, 1963, to September 30, 1964, and is specifically dedicated to all employees of the organization and their families; it thus makes available in easily undorstood language, accompanicd by generous illustrations in black-and-white and colour, much inside information, technical and economie, which would otherwise perhaps be excluded from a moro formal staternent of affairs. 1964 was a record year for steel production in the United Kingdom, as indced it was for the United Steol group. The total output of steol in Britain as a whole was $26 \cdot 2$ million ingot tons in 1964, nearly 2 million tons more than was produced in 1960 , tho best previous year. $A$ message from the chairman, Mr. A. J. Peech, in this report states: "The expectations of a prosperous outcome of the past year have been fulfilled and our works will continue to be fully occupied for, at any rate, the first part of 1965 . It is, however, particularly difficult to forecast the effect on the longer-term outlook of the present balance of payments problem and the steps which are being taken to deal with it". The impressions to be gained from perusal of this report are those of a thriving and efficiently managed industry, an appreciation of the economic difficulties of the times, ability to live with and ultimately to surmount them, and a welcome basis of mutual understanding between executive and personnel from which alone future progross in this organization can be assured, whatever the ultimate political circumstances of the steel industry in Britain as a whole.

\section{Museums Journal}

The March issue of the Museums Journal (64, No. 4; 1965 ), in accordance with recent policy, is devoted to one subject. In this case, the work of the International Council of Museums is dealt with from several angles, in papers read at a one-day conference in London of the British members of the Intornational Council. Present at the meoting was the president of the International Council, Sir Philip Hendy, who in his contribution to the conference did not minimize the difficulties facing those who want to make the International Council work well. The president of the British National Committee, Sir Frank Francis, spoke of the needs yet unmet by the Intornational Council of Museums. Other speakers gave details of schemes of museum development that they had carried out in the United States, Poland, Russia, Tanganyika and Ghana, under the aegis of the International Council.

\section{Chemical-Biological Activities}

A NEw journal, Chemical-Biological Activities, issued by the American Chemical Society, reports on the activity of organic compounds on biological systems exclusive of botanical. The digests indicate the host (if known), system (organ, etc.), function or characteristic of the system being modificd, the condition created, the significant concomitant diseases or other conditions of the host or system, and the comparative drug activity and route of administration. Each bi-weokly issue contains three indexes, which will be combined and issued semiannually. Further information can be obtained from Chemical Abstracts Service, the Ohio State University, Columbus, Ohio 43210.

\section{New Icelandic Islands: Surtsey and Surtling}

The new Icelandic island of Surtsey, born on November 15, 1963, about $32 \mathrm{~km}$ off the south coast of Iceland and $19 \mathrm{~km}$ south of the Vestmann Islands, has grown steadily since it first appeared above the waves, and by the spring of this year it had reached a height of $170 \mathrm{~m}$ and an area of $2 \cdot 3 \mathrm{sq} . \mathrm{km}$. Initially the volcano crupted. ashes and steam and the island seemed likely to perish rapidly from marine erosion, as has been the fate of several new islands which have been recorded from time to time in the sca off south-west and north-east Iceland; but in April 1964, as soon as a sufficiently strong reef of tuffs was created to exclude sea-water from the vent, lavas began to be erupted, so ensuring a greater degree of permanence. In view of tho widespread interest which the ovent aroused, the University of Reykjavik, the Museurn of Natural History, and other Icelandic institutions set up a Surtsey Rescarch Committee to co-ordinate and strengthen geophysical, geochernical, and biological studies of the island, and a first mimcographed report of the work of the Committec appeared in February 1965. Shortly after this another new volcano, now named Surtling, appeared about $0.5 \mathrm{~km}$ to the east of Surtsey. 